\title{
Korea under solen. Syd i skuggan av Nord?
}

Recension av Gabriel Jonsson, Korea igår och idag. Historia, politik och ekonomi (Appell förlag, Stockholm 2018) \& Lars Vargö, Korea. En civilisation i kläm (Carlssons, Stockholm 2019)

\section{SVEN HORT}

Den koreanska halvön omgärdas i dag av tre regionala stormakter - Kina (både militär och ekonomisk), Ryssland (militär) och Japan (ekonomisk, en gång också militär) - och en fjärde, vilken sedan kommendör Perrys kanonbåtsdiplomati I854 och det brittiska imperiets gradvisa återtåg från dominans och kontroll över de sju haven tagit över rollen som global hegemon eller riktkarl: Amerikas förenta stater. Andra världskrigets två stora segermakter delade på bytet utmed halvöns 38:e breddgrad och denna gränslinje återupprättades efter ett kort, brutalt inbördeskrig med mycken utländsk närvaro, även svensk. Något fredsfördrag slöts emellertid aldrig mellan de stridande parterna, endast ett stilleståndsavtal i Panmunjom för snart sjuttio år sedan (1953). Sovjetunionen och snart nog också Folkrepubliken Kina blev garanterna för en typ av postkolonial nyordning; USA i syd för en annan; krigen och konflikterna fortsatte. År 2020 upprätthåller i norr Kim "den tredje" - Kim Il Sungs barnbarn - kontrollen över en stat och ett landområde större men betydligt mindre befolkat än grannen i syd (knappt 25 miljoner i norr). Med ett statsterritorium stort som Götaland har de lokala härskarnas öden i syd (över 50 miljoner invånare) skiftat över de gångna sju decennierna medan de amerikanska truppernas närvaro bestått. Sedan något decennium tillbaka pågår av och till, och med växlande framgång, sexnationerssamtal om kärnvapnen på halvön mellan Nord (DPRK på engelska) och Syd (ROK) samt de fyra ovan nämnda stormakterna. 
Korea, och koreanerna - en nation och föreställd (språk)gemenskap om sammanlagt bortåt 80 miljoner människor i en region med sammanlagt långt över en miljard - har genom årtusendena råkat i kläm, milt talat, och detta i en del av världen som i dag ofta ses som planetens Framtid, dit många riktar sina blickar. "Kläm” finns också i titeln och är den bärande tankegången i diplomaten och japanologen Lars Vargös synnerligen innehållsrika Korea. En civilisation $i$ kläm (2019), en bok som också betonar mycket av det unika och klämda i den koreanska konsten, litteraturen och musiken; "själen" med hans ord. Det är den senaste av två böcker från de gångna tre åren vilka tar ett helhetsgrepp om territoriet, dess institutioner, människor och omvärld. Vargös bok är mer "japansk" och kulturell och något mindre ekonomisk än den andra: Gabriel Jonssons faktaspäckade Korea igår och idag. Historia, politik och ekonomi (2018). Jonsson är lektor i koreanska vid Stockholms universitet, en mycket uppskattad lärare att döma av det lilla jag sett och hört, och utgivare av Koreanska sällskapets medlemstidning Yoboseyo. Jonssons bok är försedd med ett förord, närmast en lång "blurb” om än inte på baksidan, av ekonomen med mera Klas Eklund, i dag på advokatfirman Mannheimer Swartling: "det första svenska översiktsverket på över 20 år" summerar den senares bidrag till den nya boken. Jonssons och Vargös akademisk-humanistiska bakgrund sätter förstås sin prägel på verken men det gör dem inte mindre värda att ta till sig med ideologikritiskt granskande blickar. Båda går utöver mer specialiserade böcker om Korea vilka också kommit ut på svenska under senare år, inte minst skildringar av, från och om Nordkorea.

Även om Jonsson ger läsaren en närmast stackatoartad hundrasidig tillbakablick på halvöns rika historia är det dagens förhållanden både i nord och syd som står i centrum för hans bok. Det moderna Korea har av en annan svensk Asienkännare kallats "Asiens Skandinavien”, kanske inte helt adekvat eller rättvist men ändå. Efter Koreakriget gick Sydkorea på mycket kort tid, en generation, från ett synnerligen fattigt land till ett av världens femton rikaste mätt i BNP-termer. I dag är Seoul en blomstrande storstad och levnadsstandarden i landet på väg mot japanska höjder. Nordkoreas återhämtning var emellertid snabbare under 1950- och I960-talen då landet drog fördel av konflikten mellan Kina och Sovjet- 
unionen och kunde spela ut och luta sig mot stöd från de båda konkurrerande socialistgiganterna. De inre förhållandena i nord skilde sig då inte märkbart från andra länder av denna typ. Först i början av 1970-talet och efter tio års brutal militärdiktatur kom syd så sakta ikapp, även om det grova inre förtrycket bestod ytterligare närmare två årtionden. 1993 valdes en icke-militär till president i ett land med en närmast amerikansk författning och där KCIA fortsatte jaga författningsfiender även efter militärdiktaturens fall. Inte minst regionala konflikter mellan Sydkoreas östra och västra halvor har sedan 1990-talets demokratisering präglat politiken i landet medan i norr Kim-familjen trots sentida brodermord suttit relativt stabilt i sadeln i Pyongyang. De bärande elementen i den grundläggande statsstrukturen i norr såväl som i syd är inte helt olika, snarare historiskt besläktade med de omgivande rikenas historiska auktoritets- och makthierarkier, därom är Jonsson och Vargö eniga.

Stabiliteten i syd har under senare decennier främjats av en snabb ekonomisk tillväxt men av och till underminerats av politiska konflikter mellan en höger (i öster) med ambitionen att erövra norr och med rötter i uppslutningen kring USA. Mot denna har stått en mer neutralistisk center-vänster (i landets västra delar) vilken strävat efter först frihet från förtryck och militärdiktatur och senare försoning och någon form av enande med nord, och med en tydlig kritisk udd riktad mot Japan och de inhemska historiska medlöparna, quislingarna i öster. Högern i sina lite olika skepnader har vanligtvis dominerat statens administrativa apparater och institutioner medan det "civila samhället" har burit fram oppositionen till den politiska presidentmakten sedan 20I7, tidigare också under en tioårsperiod 1998-2007. Folkstyret har tagit viktiga steg framåt. Detta är emellertid också en historia om klasskamp med arbetare, buddister, katoliker, kristna (protestanter i "de kommunistiska kyrkorna") och studenter "sida vid sida", först senare kom en "folklig" motreaktion i form av den kristna högerns evangelikala masskyrkor, med de senares maktutövning också katastrofer som färjan Sewols förlisning 20I4. Den dramatiska händelseutvecklingen i Sydkorea fram till 2018 kan man följa om inte dag för dag så nästan månad för månad i Gabriel Jonssons bok, särskilt i de avslutande sextio sidorna av kapitel 4 och i ett fylligt appendix ("kronologi"). I Vargös bok vävs skeendena under efter- 
krigstiden in i ett större resonerande mönster av "klämmor", inte minst med språk och religion.

Den relativa stabiliteten på halvön har under de senaste två-tre decennierna främst utmanats av den nordkoreanska kärnvapenupprustningen vilken utgör bakgrunden till de föga framgångsrika sexnationerssamtal som av och till förts. Efter Sovjetunionens sammanbrott och Kinas nya roll i världsekonomin och -politiken har det strategiska läget på den koreanska halvön emellertid förändrats. I nord i riktning mot att "alla våra grannar är våra fiender", även om Kina än så länge är en garant för DPRK:s existens. USA har behållit sina trupper i syd - än viktigare är att den sydkoreanska armen fortfarande, sedan Koreakrigets dagar, står under direkt amerikanskt befäl. Kim-familjen i norr försöker naturligtvis också försvara sitt inre våldsmonopol på olika sätt, administrativt genom den parti- och statsapparat som under lång tid byggts upp och genom åren förfinats i form av en tämligen genomtänkt klass- och befolkningsstruktur, allt under svåra ekonomiska umbäranden. Arbetarpartiet är till formen ett massparti med fyra miljoner medlemmar (enligt obekräftade uppgifter) medan armén består av samtliga män i åldersgruppen 20-28 år, den senare mer arbetsbrigader än en traditionell krigsmakt. Att många människor lider av undernäring sedan svältåren vid 1990-talets mitt är väl känt, hälsoväsendet är både undermåligt och underförsörjt medan utbildningsväsendet förmår producera ingenjörer som kan både hacka sig in i moderna datasystem och bidra till det egna kärnvapenprogrammet. Förtryck av oliktänkande är likaledes väl känt, mindre välbekant är kanske att staden Pyongyang alltmer börjar lika en småskalig variant av Seoul med nya bilar, skyskrapor och omskrivna tunnelbanelinjer, av och till besökt av en och annan amerikansk kändis, basketspelare i synnerhet. Sedan Donald Trump blev president i USA 2016 är det hans möten med Nordkoreas Kim Jong Un som fångat internationella mediers uppmärksamhet, allt på bekostnad av Sydkoreas ekonomiska "under", Hyundais, Kias och Samsungs framgångar "på marknaden". Sydkoreas tämligen framgångsrika bekämpning av corona/covid-ı9 har kanske i någon mån ändrat på situationen.

2019 kom alltså det andra "översiktsverket", Lars Vargö med sitt argumenterande, civilisationskritiska förhållningssätt till den långa och 
i många stycken anmärkningsvärda historien på den koreanska halvön. Vargö är en pensionerad svensk diplomat som varit stationerad både i Tokyo och Seoul - där han grundade ett bland stadens kulturkvinnor och -män mycket välsett skönlitterärt sällskap, Seoul Literary Society. Däremot har han inte stadigvarande varit placerad i Pyongyang som en del andra svenska UD-tjänstemän och -kvinnor. Till utbildning är han japanolog och var i sin ungdom verksam vid universitetet i Kyoto. Japans årtusendelånga, sammantvinnade kultur- och militärhistoriska relation till både Kina och Korea, krigen, och Koreas lika historiska relation till det närmast gränslösa Mittens rike, tributerna, utgör grunden till de "klämmor" som än i dag sätter sin prägel på den koreanska halvön. Donald Trumps inviter till Kim Jong Un är i ett sådant synsätt en flugskit på den världshistoriska kartan. Japans omvälvande restauration under I8oo-talets andra hälft, segrarna i både kinesisk-japanska kriget I894-I895 och rysk-japanska kriget 1904-1905, utgör den korta fond mot vilken mycket av den efterföljande stillahavshistorien utspelas. Särskilt minnena bland koreaner i både nord och syd av den japanska ockupationen under 1900-talets första hälft skaver och gör ont, inte minst för de sista överlevande sexslavarna vilka en dag en gång i månaden protesterar utanför Japans ambassad i centrala Seoul. Språket, ritualerna och föreställningsvärldarna, inte minst konfucianismen, har på halvön dock format en auktoritär politisk ekonomi och kultur, i dag såväl som i går överbestämd av globala maktkonstellationer.

Att rikta en lång civilisationskritisk blick på Korea har naturligtvis också sina risker. Optiken kan förskjuta fokus från det nära och omedelbara till det bakomliggande varvid nuets bärare både fjärmas och fjättras. Den risken hanteras på olika sätt i de båda översiktsverken. Sammantaget utgör de två böckerna en viktig introduktion till en del av världen som lätt glöms eller kläms bort när en amerikansk president lämnat den åt sitt eget öde, även i Sverige. Forskningsmässigt delar de dock en fundamental svaghet. Båda författarna antyder att de läst åtminstone några av Chicago-professorn Bruce Cumings samtida, epokgörande arbeten om de samhälls- och statsbildningar som funnits och finns på detta territorium i norr såväl som i syd och de djupgående motsättningar bortom ont och gott vilka sätter sin prägel på dagens situation i öst liksom i väst. 
ARKIV | NR I2 | RECENSION

Cumings besökte den svenska huvudstaden häromåret och studenterna i koreanska fyllde universitetets Aula Magna, men några spår därutöver lämnade han inte, mig veterligt. Lokala medier föreföll helt ointresserade av detta svenska kunskapslyft. För den engelskläsande är det dock bara att gå vidare, till exempel med Korea's place in the sun. ${ }^{\text {I }}$

För svenskt och nordiskt vidkommande är det emellertid ett sundhetstecken att de två böckerna av Jonsson och Vargö nu finns till hands, kan kritiskt inmundigas på egen hand eller diskuteras och "diskursas" tillsammans med andra Nordostasienintresserade, ja även av läsare intresserade av långt mer än detta avgränsade landområde - i rum såväl som tid och rymd, av planeten under solen.

I. Bruce Cumings, Korea's place in the sun. A modern history. New York: W.W. Norton \& Company, uppdaterad upplaga 2005 . 

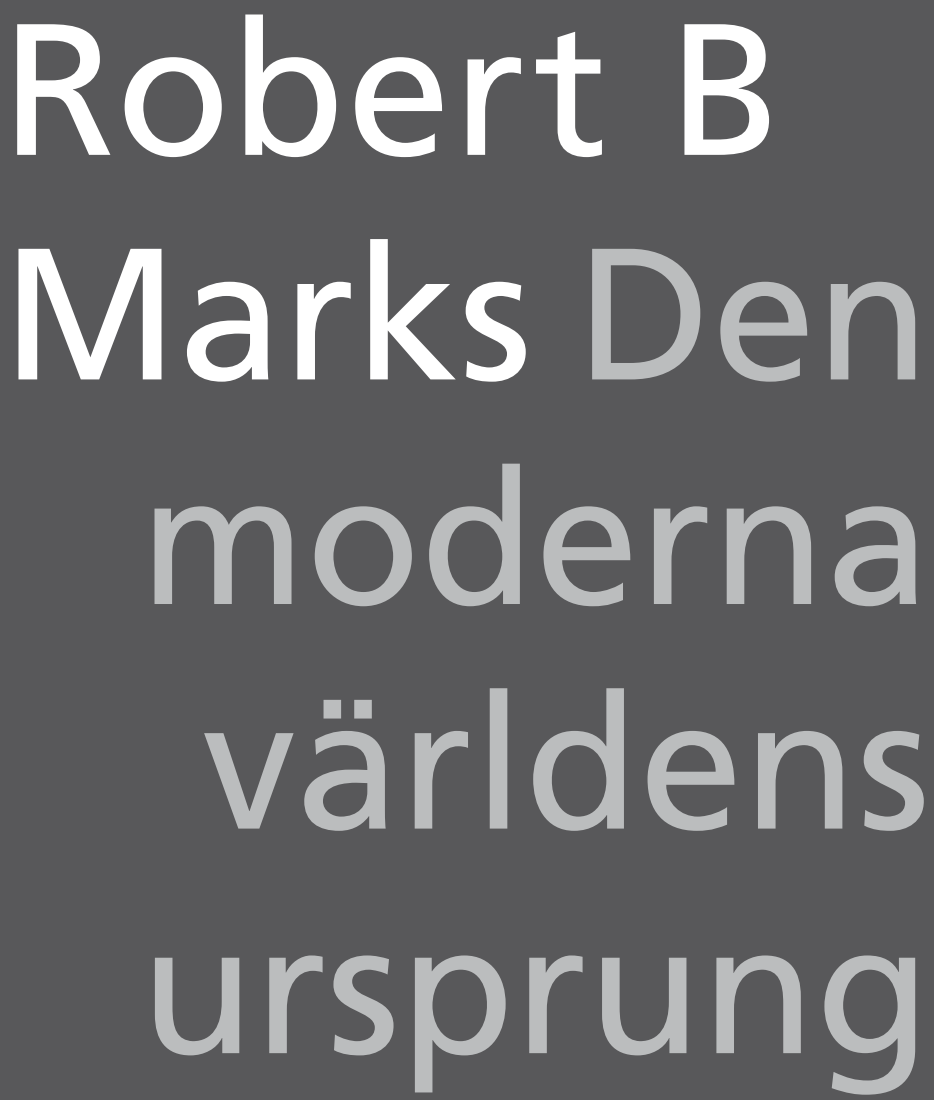

I denna lättillgängliga och fängslande bok skildras den moderna världens ursprung i ett sant globalt perspektiv. Istället för att handla om "västerlandets uppgång", stödjer den sig på ny kunskap och tilldelar Asien, Afrika och Nya världen viktiga roller i berättelsen.

Arkiv förlag, 208 sidor

»Läs mer om boken på www.arkiv.nu« 


\section{Moderna klassiker}

\section{Marshall Berman \\ Allt som är fast \\ förflyktigas}

\section{Arkiv förlag}

I denna sällsynt rika och fängslande bok utforskar Marshall Berman en upplevelse som präglat alla samhällen och människor som dragits in i den kapitalistiska omvälvningen av världen: upplevelsen av en modernitet där inget är bestående och stabilt, där traditionella livsformer och tänkesätt raseras. I konsten, litteraturen, musiken och arkitekturen fångas denna samhälleliga omvälvning av modernismen.

Övers. Gunnar Sandin, 442 sidor 